\title{
Quantitative Research on the Influencing Factors of Green Building Development
}

\author{
Weize Zhao*, Yang Liu, Lu Niu
}

School of management science and engineering, Anhui University of Finance and economics, Bengbu 233000, Anhui Province, China. E-mail:1424195403@qq.com

\begin{abstract}
The rapid development of national economy is closely related to the environmental protection and the rapid development of green buildings. The development of green building has always been the focus of national development research. It is undeniable that it has a crucial impact on the exploration of the factors affecting the development of green building. Undoubtedly, the research on the factors affecting the development of green building plays a vital role in the progress of the national construction industry and the vigorous development of the government's green environmental protection. This paper first determines the green real estate index as an indicator of the impact of green building, and then on this basis, studies the main factors affecting the growth of green building area and the degree of impact by using the method of quantitative analysis of data. Finally, based on the results of the analysis, the corresponding policy recommendations are put forward.
\end{abstract}

Keywords: Green Building; Influencing Factors; Econometric Analysis; Empirical Research

\section{Introduction}

At present, China is gradually in a period of rapid promotion and development from rural areas to industrialization, urbanization and new rural modernization. However, there are still many problems in the development of the rural and urban-rural economy. For example, the growth speed is still not fast than expected and the development is unbalanced. In addition, the building quality, energy consumption and energy efficiency are relatively low. Therefore, it is of great significance to accelerate and promote the development of China's green engineering construction industry. In detail, it shall guide the housing and urban-rural construction and construction engineering enterprises to take the road of green building development so as to achieve a low-cost development. It shall construct low-carbon building with zero emission, maximum resource saving, high utiliza- tion rate and minimum environmental impact, which has become the best way of ideal urban and rural development. In the process of urbanization, we should reduce the environmental restrictions on utilizing resources and strengthen and improve the integration of building energy saving, land saving, water saving, material saving, environmental protection and other technologies, so as to drive the innovation of building technology as far as possible and promote the basic reform of the production mode of the construction industry, thus maximally promoting the modernization of the construction industry. It will also promote the rapid development of building materials, new energy applications, energy conservation and environmental protection services and consulting services related to energy conservation and environmental protection, good environment and green development.

The proportion of green buildings in new buildings

Copyright (C) 2021 Weize Zhao et al.

doi: $10.18686 /$ pes.v3i1.1372

This is an open-access article distributed under the terms of the Creative Commons Attribution Non-Commercial License (http://creativecommons.org/licenses/by-nc/4.0/), which permits unrestricted non-commercial use, distribution, and reproduction in any medium, provided the original work is properly cited. 
should be effectively increased. By 2020, green buildings will account for more than $30 \%$ of new buildings, and energy consumption level in the process of building construction and use will be close to or reach the level of developed countries at this stage. During the "12th Five Year Plan” period, we should strengthen the capacity-building in such aspects as policy incentives, standards and specifications, technological progress, industrial support, as well as certification and evaluation, so as to establish a system and mechanism conducive to the development of green buildings and promote the evaluation and identification of new single buildings and the centralized promotion of new urban areas, thus realizing the rapid development of green buildings ${ }^{[1]}$.

\section{Analysis of influencing factors}

\subsection{Analysis on the influencing factors of green building development}

Green building is a kind of building that is harmless to the environment, which can make full use of natural resources and can achieve sustainable development without damaging the basic ecological balance of the environment. In terms of economic consumption related to people's daily life, there are seven main factors affecting the development of green buildings in the development of buildings by major construction companies ${ }^{[2]}$.

(1) New construction area: the new construction area has a direct impact on the green construction area. Obviously, with the increase of new construction area, the area of green building will also increase. In order to comply with the development trend of the country and keep up with the conception of environmental protection advocated by the Party Central Committee, more companies will gradually choose to expand the construction area of green buildings and better implement the green buildings, so as to reduce the pollution of people's daily life.

(2) One star area of green building: the one star area of green building is the sum of the total area of buildings whose building standard reaches one star. Only when the total score reaches 50 can the building be rated as one star building. Correspondingly, one star green building has higher requirements for energy saving, water saving, land saving and material saving. The more areas of one star green building are, the faster the development of green building will be.

(3) The proportion of one star green building area in the total newly started area: it shall increase the proportion of one star green building area in the newly started area, which is conducive to improving the development of green buildings. The newly started building area can be divided into many aspects. Moreover, it is necessary to reduce the proportion of traditional building area and increase the proportion of green building area, which will accelerate the development of green building.

(4) Area of two star and three-star green buildings: two star and three-star green buildings also belong to the category of green buildings. The increase of the two areas has a positive role in promoting the increase of the total area of green buildings and the development of green buildings.

(5) The proportion of two-star and three-star green building area in the total area of new construction: the higher the proportion of two-star and three-star green building area is, the better the development of green building will achieve.

(6) Prefabricated area: at present, many prefabricated buildings in the market use green building materials, which makes some prefabricated buildings become a member of green buildings. Prefabricated building itself has the characteristics of energy saving and environmental protection, which can greatly save materials and manpower. Since its advantages are very similar to the requirements of green building, prefabricated building also has a great impact on the development of green building.

(7) Area of fully decorated finished houses: the area of fully decorated finished houses also promotes the development of green buildings in some aspects. More green decoration materials appear in the market, which also imperceptibly affects people's choice of green buildings to live in, and stimulates the real estate companies to increase their choice of green buildings. Thus there will be an increase in total area of green buildings.

\subsection{Determination of explanatory variable and explained variable}

(1) Explanatory variables: to determine the new construction area, green building one star area, green building one star area in the proportion of the total 
new construction area, and determine the two stars green building, three stars area, green building two stars, three stars area in the proportion of the total new construction area, prefabricated area, fully decorated finished house area to study the influence of these factors on the explanatory variables.

(2) Explained variable: for the development of green building, this paper selects the green real estate index as the index to measure the development of green building. $\mathrm{Y}=\mathrm{R} \times 50 \%+\mathrm{A} \times 30 \%+\mathrm{N} \times 10 \%+\mathrm{K} \times 10 \%$. Among them, $\mathrm{G}$ stands for the green property index with a full score of 100 , and $\mathrm{R}$ stands for the conventional index of green property, which is calculated by $50 \%$, and a stands for the incentive index of green property, which is calculated by $30 \%$, and $n$ stands for the green information transparency index, and $\mathrm{K}$ stands for the green market efficiency index, and $\mathrm{N}$ and $\mathrm{K}$ are calculated by $10 \%$. In this paper, the green property index is selected as the data result. Green real estate index (y) is used as the explained variable to reflect the development status of green buildings. The higher the development index is, the better the development status of green buildings will be.

\section{Variables and data}

\subsection{Explanatory variable and explained var- iable}

$\mathrm{X} 1$ - new construction area / $10000 \mathrm{~m}^{\wedge} 2$

X2 - one star area of green building / $10000 \mathrm{~m}^{\wedge} 2$

$\mathrm{X} 3$ - the proportion of one star green building area in the total new construction area

X4-two star and three-star green building area / $10000 \mathrm{~m}^{\wedge} 2$

X5 - the proportion of two star and three-star green building area in the total new construction area

X6-assembled area / $10000 \mathrm{~m}^{\wedge} 2$

X7-fully decorated finished house area / 10000 $\mathrm{m}^{\wedge} 2$

$\mathrm{Y}$ - green property index

\subsection{Construction related data of 30 real estate enterprises in China}

\begin{tabular}{|c|c|c|c|c|c|c|c|c|}
\hline Enterprise abbreviation & $\mathbf{Y}$ & $\mathbf{X 1}$ & $\mathrm{X} 2$ & X3 & X4 & X5 & X6 & $\mathbf{X 7}$ \\
\hline Jinmao, China & 25.7 & 1222 & 1177 & $96.32 \%$ & 368 & $30.11 \%$ & 642 & 565 \\
\hline Vanke Group & 24.2 & 4993 & 2626 & $52.59 \%$ & 876 & $17.54 \%$ & 1458 & 0 \\
\hline CNOOC real estate & 23.9 & 1881 & 899 & $47.79 \%$ & 269 & $14.30 \%$ & 277 & 1390 \\
\hline Country garden & 23 & 5416 & 2708 & $50 \%$ & 712 & $13.15 \%$ & 544 & 0 \\
\hline China Evergrande & 23 & 7567 & 2507 & $33.13 \%$ & 624 & $8.25 \%$ & 35 & 2661 \\
\hline First real estate & 20.6 & 738 & 60 & $8.13 \%$ & 183 & $24.80 \%$ & 407 & 663 \\
\hline Gezhouba Real Estate & 20.6 & 469 & 0 & $0 \%$ & 100 & $21.32 \%$ & 100 & 100 \\
\hline Contemporary Real Estate & 16.5 & 360 & 20 & $5.56 \%$ & 127 & $35.28 \%$ & 0 & 0 \\
\hline Green city China & 15.7 & 635 & 41.9 & $6.60 \%$ & 338 & $53.23 \%$ & 155 & 246 \\
\hline Longhu Group & 15.5 & 1954 & 1277 & $65.35 \%$ & 348 & $17.81 \%$ & 480 & 0 \\
\hline Landsea Green Group & 13.9 & 199 & 6 & $3.02 \%$ & 51 & $25.63 \%$ & 24 & 94 \\
\hline Baolong Real Estate & 13.8 & 402 & 234 & $58.21 \%$ & 165 & $41.04 \%$ & 31 & 2 \\
\hline China Merchants Shekou & 13.8 & 1847 & 176 & $9.53 \%$ & 152 & $8.23 \%$ & 569 & 0 \\
\hline Ocean Group & 13.5 & 608 & 381 & $62.66 \%$ & 169 & $27.80 \%$ & 137 & 0 \\
\hline Jinke Group & 12.7 & 1800 & 645 & $35.83 \%$ & 91 & $5.06 \%$ & 144 & 154 \\
\hline Taihe Group & 12.7 & 535 & 164 & $30.65 \%$ & 30 & $5.61 \%$ & 18 & 26 \\
\hline Rongsheng Development & 12.4 & 993 & 229 & $23.06 \%$ & 65 & $6.55 \%$ & 3 & 0 \\
\hline Shui On Land & 12.3 & 45 & 0 & $0 \%$ & 30 & $66.67 \%$ & 0 & 28 \\
\hline Jianye Group & 12.2 & 1067 & 348 & $32.61 \%$ & 242 & $22.68 \%$ & 0 & 0 \\
\hline Greenland Holdings & 11.9 & 9873 & 0 & $0 \%$ & 295 & $2.99 \%$ & 737 & 0 \\
\hline Poly Development & 11.8 & 4396 & 32 & $0.73 \%$ & 143 & $3.25 \%$ & 47 & 47 \\
\hline Dongyuan Real Estate & 11.7 & 54 & 28 & $51.85 \%$ & 22 & $40.74 \%$ & 0 & 0 \\
\hline
\end{tabular}




\begin{tabular}{|l|l|l|l|l|l|l|l|l|}
\hline Chinese Enterprises & 11.3 & 24 & 0 & $0 \%$ & 20 & $83.33 \%$ & 11 & 1 \\
\hline Beijing Housing General Office & 11.2 & 35 & 0 & $0 \%$ & 5 & $14.29 \%$ & 19 & 13 \\
\hline Shimao Real Estate & 11.1 & 1222 & 0 & $0 \%$ & 235 & $19.23 \%$ & 0 & 0 \\
\hline SCE Group & 10.9 & 426 & 0 & $0 \%$ & 73 & $17.14 \%$ & 0 & 0 \\
\hline Zhongnan Real Estate & 10.7 & 1158 & 0 & $0 \%$ & 171 & $14.77 \%$ & 0 & 0 \\
\hline China Resources Land & 10.6 & 1206 & 0 & $0 \%$ & 165 & $13.68 \%$ & 0 & 0 \\
\hline Impression of Sanxiang & 10.5 & 137 & 0 & $0 \%$ & 12 & $8.76 \%$ & 0 & 12 \\
\hline Rongchuang China & 10.4 & 3020 & 0 & $0 \%$ & 189 & $6.26 \%$ & 0 & 0 \\
\hline Blue Ray Development & 10.3 & 1026 & 0 & $0 \%$ & 81 & $7.89 \%$ & 0 & 0 \\
\hline Yuzhou Real Estate & 10 & 405 & 0 & $0 \%$ & 30 & $7.41 \%$ & 0 & 0 \\
\hline Xiangsheng Real Estate & 9.6 & 744 & 0 & $0 \%$ & 35 & $4.70 \%$ & 0 \\
\hline Zhengrong Real Estate & 8.8 & 907 & 0 & $0 \%$ & 46 & $5.07 \%$ & 0 & 0 \\
\hline Note: data are from global magazine & & & & & & \\
\hline
\end{tabular}

Figure 1. 2018 Construction related data of 30 real estate enterprises in China.

\section{Establishment and test of the model}

\subsection{Analysis of correlation chart and trend chart}

By importing the data into Eviews 9.0 software, we can learn from the trend chart that each explanatory variable has the same change direction as the explained variable, but there are very few explanatory variables with special circumstances. From the correlation diagram, the results show that there is a high positive linear correlation between most of the explanatory variables and the explained variables.

$Y=\alpha+\beta_{1} X_{1}+\beta_{2} X_{2}+\beta_{3} X_{3}+\beta_{4} X_{4}+\beta_{5} X_{5}+\beta_{6} X_{6}+\beta_{7} X_{7}+\mu$

\subsection{Regression model analysis}

After statistical test, econometric test, statistical test and econometric test, the autocorrelation test is adopted in the process of econometric test, and the generalized difference method is used to modify the model, and the autocorrelation test is carried out. 4.3 Determine the final model

$\mathrm{Y}=12.3744+0.0020 * \mathrm{X} 2+0.0050 * \mathrm{X} 7+0.0090 * \mathrm{X} 6-$ $0.0008 * \mathrm{X} 1(0.531055)(0.000870)(0.001059)(0.002003)$ (0.000246)(23.30157)(2.354805)(4.726587)(4.471461)

$(-3.118675)=0.780348$

$0.750052 \mathrm{DW}=1.461385 \mathrm{~F}=25.75682 \operatorname{prob}(\mathrm{F})=0.000000$ $=2.430408=171.2996$

The model shows that when the one star area of green building x2 increases by 10000 square meters, the green real estate index y will increase by 0.000870 on average; When X7 increases by 10000 square meters, the green property index y will increase by 0.001059 on average; when X6 increases by 10000 square meters, the green property index y will increase by 0.002003 on average; when X1 increases by 10000 square meters, the green property index y will decrease by 0.000246 on average.

\section{Conclusion and suggestion}

Nowadays, the role of green building development in the national economic growth is increasing. It is essential to promote the development of green building. With the economic development, people's quality of life is also higher and higher. The development of green building is affected by many factors, namely, new building area, green building area of one, two or three stars and its proportion in the new building area, fully decorated finished house area and prefabricated building area. This paper shows that the development of green building in China is mainly affected by one star green building area, fully decorated finished house area and prefabricated building area through econometric method. With the increase of one star green building area, the development of green building is faster. At the same time, the increase of the area of fully decorated finished houses and the increase of prefabricated building area will also accelerate the development of green buildings 
in China. People's attention to green and environmental protection promotes the rapid development of green buildings in an all-round way, which fully meets the needs of the future development of the country.

According to the final conclusion of this paper, this paper puts forward the following suggestions for the development of green building.

First, it shall accelerate the construction and development of one star green building. In the process of engineering development and construction, green building materials should be used as much as possible to improve the sign and quality of construction engineering. Moreover, it shall increase the building area of one-star buildings in green buildings, including public buildings and residential projects. Building energy consumption accounts for $50 \%$ of the energy consumption of the whole society, so it is particularly important to improve the area of the building and reduce the gas and solid waste generated in the construction process. One of the main ways to reduce social energy consumption is to promote green energy-saving buildings.

Second, it shall improve the area of finished houses. The whole decoration requires the integrated design of residential building and civil engineering installation. In this integrated design, it is easier to use integrated green building materials. The development of green building has become the goal of the whole society, and the development of green building into the fully decorated finished house is the general trend in the future.

Third, it shall develop new construction methods and vigorously promote prefabricated buildings. We should promote the modernization of the construction industry and promote the intellectualization and assem- bly of buildings by adhering to standardized design, industrial production, assembly, equipment integration, information management, intelligent application and innovation of building methods, so as to vigorously develop prefabricated buildings. In recent years, with the gradual development of China's residential decoration market, consumers' acceptance and demand for fully decorated houses have increased. China's architectural decoration industry has become one of the three pillar industries of the construction industry. With the rapid growth of China's economy and the vigorous development of related industries, the building decoration industry shows more and more great development potential. The residential decoration market has become an important part of the sustainable development of the building decoration industry and an important profit growth point. Therefore, in the era of rapid economic development, the promotion of prefabricated construction industry is conducive to the development of green buildings ${ }^{[3]}$.

\section{References}

1. Ministry of Finance and Ministry of housing and urban rural development. "Implementation Opinions on accelerating the development of green building in China”: establishing incentive mechanism of green building fiscal policy. Construction Science and Technology 2013; (06): 14.

2. Gong R, Ren P, Cai W. Development direction and suggestions of green building based on consumer perspective: a case study of Chongqing (in Chinese). Construction Economy 2015; 36 (8): 84-87.

3. Liu D. Promoting prefabricated decoration to accelerate the development of prefabricated Architecture(in Chinese). Construction and Architecture, 2016 (22): 11-15. 